značného komparativního př́ípadu z dějin evropské historie a srovnávací mytologie, ale též jako krásná ukázka badatelské spolupráce a dialogu dvou vědců, kteří mají $\mathrm{k}$ dané problematice diametrálně odlišný přístup a vyvozují ze stejných dat různé závěry, avšak díky trpělivé a vstř́íné diskuzi dokážou najít společné jmenovatele pro ustanovení alespoň několika konsensuálních závěrů.

Rozprava Ginzburga a Lincolna nad př́ipadem starého Thiesse otevírá celou řadu obecných teoretických a metodologických otázek, v odpovědích na něž se sice oba autoři různí, ale jsou ochotni debatovat o tom proč: Je záhodno ve vědě postulovat riskantní řešení? Může být hapax legomenon (tj. jedinečný doklad) v historickém bádání přesvědčivým důkazem? Může být srovnávací př́istup př́inosný i v době popularity partikulárních a kontextově citlivých studií?

Zajímavá je i počáteční epistemologická asymetrie: Ginzburg v zásadě souhlasí s Lincolnovým náhledem a nemá větší problém začlenit jej do své hypotézy (diskurzivní rovina soudních výpovědí, ač možná motivovaná analogickou socioekonomickou situací, jednoduše může čerpat ze společného základu příbuzných symbolických soustav), ale Lincoln s obecností Ginzburgova postoje nesouhlasí a považuje jej nejen za chybný, ale i nebezpečný. Tato nevyrovnanost je v závěru lehce překročena, když Lincoln uzná (s. 187-188), že nemá výklad pro některé motivy, které Thiess $\mathrm{v}$ procesu uvádí a které Ginzburgův př́istup umí objasnit lépe (pokud navíc do sebe integruje Lincolnovu diskurzivní analýzu), a následně navrhuje znovuotevření kontextuálně citlivého bádání nad komparativními případy z celého světa, jež Ginzburg nashromáždil (s. 193). Snad se někdy dočkáme syntézy, která by zohledňovala sociologický i symbolický rozměr Thiessova podání, byt zcela bezrozporné závěry $\mathrm{v}$ tomto př́ipadu z povahy věci očekávat nemůžeme nikdy, jak autoři také otevřeně přiznávají. Škoda jen, že v knize kromě odkazu v seznamu další četby nijak nezohledňují kritiku a práci, kterou na poli bádání o vlkodlacích vykonal Willem de Blécourt a jeho žáci (např. Willem de Blécourt [ed.],
Werewolf Histories, London: Palgrave Macmillan 2015).

Vedle skutečnosti, že tato monografie bude moci v budoucnu sloužit jako exemplární úvaha nad srovnávacím přístupem a jako nepominutelné východisko pro jakékoliv další bádání k tématu evropských vlkodlaků a extatických soubojů, je celý dialog Ginzburga s Lincolnem v této knize nádhernou ilustrací, jak plodná, fascinující a inspirativní může být badatelská diskuze, když je vedena kultivovaně, věcně a vstřícně $\mathrm{k}$ postojủm oponenta.

JIŘí DYNDA

\section{Tanya M. Luhrmann, How God Becomes Real: Kindling the Presence of Invisible Others,}

\section{Princeton - Oxford: Princeton University Press 2020, 256 p.}

\section{ISBN 978-0-691-16446-5.}

Gods, spirits, and various invisible others are presumably part of every human culture. Cognitive and evolutionary sciences of religion (CESR) study spirits and gods as natural products of the human mind and human behavior. Does this mean that gods and spirits are mere byproducts of our cognition, illusions grounded in fictional realities? Tanya M. Luhrmann introduces a fresh and fascinating anthropological perspective on this challenging question. According to Luhrmann, we should not ask whether people "believe and therefore see" various invisible others, the objective existence of which Luhrmann herself does not 
intend to debate (p. xiv). Instead, Luhrmann tries to observe the "how" - that is, how people themselves make gods real and interact with them in everyday relationships, and how these relationships change their bodies and minds in parallel (p. xii). Luhrmann opens up a vivid and exciting world of lived faith, taking us on a journey through in-depth interviews and her personal spiritual experiences to the deep layers and learning possibilities of human bodies and minds.

Though CESR scientists are often accused of using vocabulary that is too technical and hard to understand, Luhrmann is aware of these pitfalls and presents her theory in widely accessible language and in an easily understandable way, even asking readers to be patient when introducing more complex information (p. 111). The book is divided into seven chapters, each presenting one partial hypothesis substantiated by rich interview samples and evidence from quantitative datasets gathered throughout the author's career. Luhrmann conducted her anthropological research among many different religious groups: starting with middle-class witches, pagans, and druids in her dissertation project, she moved among various Christian Churches worldwide, orthodox US Jews, Anglo-Cuban Santeria, and Thai Buddhists. She primarily uses the participant observation method and in-depth interviewing, whose analysis is interwoven throughout the whole book. Luhrmann even developed a new interviewing method called "comparative phenomenology". This method aims to gather participants' anomalous experiences in profound phenomenological detail (pp. 121-126). It is also noteworthy that the author does not hesitate to color her argument with relevant examples from her own life.

Aside qualitative methods, Luhrmann used questionnaires to quantitatively measure specific psychological traits or aspects of anomalous experience inside the respective communities. As Luhrmann was trying not to overwhelm readers with statistics and other detailed information, the acknowledgment section presenting further empirical analyses is a welcome addition. The overall composition of the book is thorough, and Luhrmann presents her arguments without unnecessary diversions, although sometimes the text is repetitive - perhaps to make the argument more understandable.

In chapter one, Luhrmann introduces us to the concept of the faith frame. She argues that probably nowhere in the world do beliefs about gods and spirits exhibit correspondence to beliefs about ordinary things like tables or chairs. Thus, Luhrmann counters the common anthropological view that the difference between the natural and the supernatural is specific to post-enlightenment societies (pp. 3-5). Luhrmann argues that the faith frame represents a special mode of thinking and acting: a play-like, as-if mode, overlapping everyday life. But unlike a game, the faith frame is serious in its real-life consequences. She continues that to keep one's mind occupied by an "as-if" better world, which faith may provide, takes a great cognitive effort - especially in the face of direct contradictions to the as-if better world. Thus, making gods more real may help people merge this "play-like faith frame" with ordinary life (pp. 22-24).

Subsequently, Luhrmann argues that one of the key factors in the real making of faith and relationships with invisible others is a good narrative, one that is detailed to the extent that it becomes personally vivid, constructed so richly that people can share its world (pp. 28-32). Accordingly, in the second chapter, Luhrmann conceptualizes religion as a paracosm, in many aspects similar to fictional paracosms provided by books or movies. However, a paracosm of faith introduces us to its characters as beings requiring real-life interaction. It describes how invisible others can participate in our lives, how we can address them through specific actions, and how spirits can "talk back" (p. 32). Furthermore, the ability to personally experience gods and spirits is, as Luhrmann explains in the third chapter, enabled by the psychological capacity for "absorption" and by the training of practitioners' imaginative abilities (p. 60). Of particular note is Luhrmann's fieldwork observation that people trained in spiritual imagination (modern-day magicians, specifically) do not have "just" different ideas about the world: they experience the world differently (p. 65). She presumes that their 
inner imagination could override incoming sensory information due to the talent for absorption and imaginative training. People of faith (i.e., people living in the faith frame) can thus experience the world as responsive, anthropomorphic, full of invisible others (p. 69).

Interestingly, Luhrmann further argues that different cultural concepts of mind can also facilitate personal experiences with god(s) (pp. 80-84). In the fourth chapter, she introduces us to her comparative anthropological research of three charismatic evangelical churches: one in the US (Vineyard), one in Ghana (Accra), and one in India (Chennai). She presents another excellent observation that the mind/world boundary is not a given. On the contrary - it is an outcome of several culturally-based judgments about the human mind and its possibilities. This schema then affects how we perceive and experience the world (pp. 106-108).

Subsequently, Luhrmann presents her theory of the "kindling" of spiritual presence: small "carbons" of personal sensory evidence can kindle a "fire" of a feeling of the realness of invisible others. She argues that "spiritual presence events" are learned by prolonged training based on what respective cultures consider significant aspects of religious experience (p. 120). The fifth chapter mentions another great CESR scientist concerned with religious experience, Ann Taves, and her "building block approach" (pp. 113-115). Following Taves, Luhrmann mentions predictive processing theory, a theory with great promise for CESR religious experience research (p. 118). Given Luhrmann's overall focus on cultural learning, hypothetical "sensory overrides", and other related assumptions, it is perhaps surprising that she does not work with predictive processing to a greater depth. Nevertheless, Luhrmann highlights an important related problem: why in the same cultural context (even inside the same religious group) people have different or variously intense spiritual experiences. For Luhrmann, it is how much we are constrained by our physical and psychological abilities that determine whether or not we are able to speak with gods, no matter how hard we try (pp. 118-120). Nevertheless, as she remarks, all faith people probably experience the world differently from secular people, for the subjective evidence of the invisible other's existence is inscribed in their bodies and minds (p. 135).

In the sixth chapter, Luhrmann discusses the old question of the psychology of religion: "why prayer works", i.e., the psychological and physiological effects of prayer. She understands prayer as a kind of metacognitive practice, similar to cognitive-behavioral therapy or mindfulness: prayer changes how people think about their mental processes, what aspects of reality they choose to think about and how (pp. 139146). Furthermore, she notes that to pray is more than talking to yourself: when people pray, they open relationships with invisible beings and speak in an "as-if" public space. Prayer is no mere monologue, nor simple thought. According to Luhrmann, what is spoken publicly has the power to change us. Consequently, addressing invisible others can make us feel them as more real - so real that people can be angry at their god if he/ she "disagrees" with their wishes (pp. 151153). In Luhrmann's book, these subtle observations are most valuable.

In the final chapter Luhrmann explicitly presents her most crucial claim: that people of faith have personal relationships with their gods and spirits that are similar to other human relationships. Consequently, she argues that anthropologists should shift their focus from beliefs and ideas to observing how gods and spirits become real in social relations - and how this "real becoming" changes people (pp. 158; 180-181). According to Luhrmann, gods are not mere metaphors, nor objects like tables and chairs. They are invisible and yet real for many people. They are brought to life in sensorial evidence-based relationships, which people commonly engage in worldwide (pp. 183-184).

Luhrmann's view on religion and faith is fresh and enriching. In her subtle way, she brings us a unique anthropological perspective on religion, complex enough to resemble the old-fashioned "big theories" of religion. Aware of her scientific predecessors, she actively refers to older theories of religion and deals explicitly throughout the 
book with the most relevant ones. Similarly, she deals actively with possible critiques of her claims. We can speculate further about specific details - for example, why the role of rituals is diminished (Luhrmann seems to take rituals as serving merely for the embodiment of faith narratives). Unfortunately, the text is not explicit enough for the reader to decide whether Luhrmann is simply focused more on narratives and faith or whether she understands ritual as subjected to faith ideas. A more profound discussion on the nature of the psychological and neurological processes behind religious experience and cultural learning would also have been welcome. These processes are crucial for personal religious experiences and cannot be reduced to one psychological disposition (i.e., absorption) and its training. However, taken as a whole, Luhrmann's book is a carefully elaborated anthropological observation of the most peculiar yet ordinary human experience - the experience with invisible others. Her sensitive approach offers valuable insights into the research of religion in an interdisciplinary context. Given the book's easily accessible language, Luhrmann's work may at least serve as a perfect invitation for the broader field of humanities to become better acquainted with CESR research.

JANA NENADALOVÁ

Religio: Revue pro religionistiku 29/1, 2021, 93-96.

https://doi.org/10.5817/Rel2021-1-6

This work can be used in accordance with the Creative Commons BY-NC-ND 4.0 International license terms and conditions (https://creativecommons.org/licenses/by-nc-nd/4.0/).

\section{Petr Sláma, Exodus I, 1-15: Jak jsem zatočil s Egyptem: Český ekumenický komen- tář ke Starému zákonu 2/1,}

\author{
Praha: Centrum biblických \\ studií AV ČR a UK v Praze 2020, \\ $416 \mathrm{~s}$.
}

\section{ISBN 978-80-7545-054-8.}

Kniha Exodus je patrně nejsložitější knihou Pentateuchu, zejména pro rozmanitost materiálů, ze kterých je komponována. Ve své první části přitom vypráví o základní události židovské Bible, kterou je vyvedení Izraelců z egyptského otroctví, a uvádí také způsob pravidelné každoroční oslavy této události během jarních svátků. Toto vyvedení je zde zároveň vylíčeno jako Hospodinovo sebe-zjevení, jako představení Hospodinova jména, proto patří tyto biblické látky mezi nejreflektovanější a nejkomentovanější, a to jak v židovské, tak křestanské tradici. Tyto skutečnosti předznamenávají, že autor komentáře středního rozsahu bude patrně zápasit o to, co všechno do svého komentářre ještě zahrnout a co už naopak ponechat bokem.

Petru Slámovi, který je učitelem Starého zákona na Evangelické teologické fakultě Univerzity Karlovy, se výběr toho nejrelevantnějšího povedl zdařilým zpơsobem. Jeho komentář vychází v ediční řadě Český ekumenický komentár ke Starému zákonu, která navazuje na kolektivní dílo Českého ekumenického překladu. Ten vycházel od roku 1968 s průběžným komentářem a dosáhl počtu šestnácti svazků, z nichž druhý, vydaný v roce 1975, byl věnován knihám Exodus a Levitikus. Od té doby, pokud je autorovi recenze známo, v češtině souvislý komentář ke knize Exodus nevyšel. Seznam současnějších cizojazyčných komentářů, které Petr Sláma ve svém díle konzultuje, je součástí závěrečného seznamu literatury. Způsob, jakým z této široké nabídky informací k biblickému textu vybral, obohatil 